RASĀYAN J. Chem.

Vol. 12 | No. 4 |2210 - 2217| October - December | 2019 ISSN: 0974-1496 | e-ISSN: 0976-0083 | CODEN: RJCABP

\title{
STUDYING IMPACT OF CITRIC ACID-BISMUTH NITRATE PENTAHYDRATE RATIO ON PHOTOCATALYTIC ACTIVITY OF BISMUTH OXIDE PREPARED BY SOLUTION COMBUSTION METHOD
}

\author{
Y. Astuti ${ }^{1, *}$, A. Fauziyah ${ }^{1}$, H. Widiyandari ${ }^{2}$ and D. S. Widodo ${ }^{1}$ \\ ${ }^{1}$ Chemistry Department, Faculty of Science and Mathematics, Diponegoro \\ University,50275, Semarang, (Central Java) Indonesia \\ ${ }^{2}$ Physics Department, Faculty of Mathematics and Natural Sciences, Sebelas Maret \\ University,57126, Surakarta, (Central Java) Indonesia \\ *E-mail: yayuk.astuti@live.undip.ac.id
}

\begin{abstract}
Bismuth oxide can be synthesized by solution combustion method. One of parameters that must be considered on the synthesis using this method is fuel-oxidant ratio $(\phi)$ since it influences the physicochemical preperties such as morphology, the particle size and crystal structure of the obtained products which further affect on their photocatalyc activity. This research used citric acid as fuel and $\mathrm{Bi}\left(\mathrm{NO}_{3}\right)_{3} \cdot 5 \mathrm{H}_{2} \mathrm{O}$ as oxidant. This study aims to investigate impact of citric acid-bismuth nitrate pentahydrate (fuel-oxidant) ratio on the physichochemical properties and photocatalytic activity of the obtained products on degradation of methyl orange. The results showed that all the obtained products contained the mixture of $\alpha-\mathrm{Bi}_{2} \mathrm{O}_{3}$ (monoclinic) dan $\beta-\mathrm{Bi}_{2} \mathrm{O}_{3}$ (tetragonal) with irregular shape coral reef-like and in aglomerate form. In addition, the fuel-oxidant ratio does influence the products' particle size in which the particle size of the products prepared by a ratio of $\phi>1, \phi=1$, and $\phi<1$ are about 5-8 $\mu \mathrm{m}, 6-10 \mu \mathrm{m}$, dan 9$14 \mu \mathrm{m}$, consecutively. Result of photocatalytic activity shows product synthesized with a ratio of $\phi>1$ has the highest photocatalytic activity.

Keywords: Bismuth Oxide, Solution Combustion, Fuel-oxidant, Photocatalyst, Photocatalysis
\end{abstract}

(C) RASĀYAN. All rights reserved

\section{INTRODUCTION}

Bismuth oxide $\left(\mathrm{Bi}_{2} \mathrm{O}_{3}\right)$ is a metal oxide with a pale yellow solid ${ }^{1}$ and melting point of $825^{\circ} \mathrm{C}^{2}$ Bismuth oxide $\left(\mathrm{Bi}_{2} \mathrm{O}_{3}\right)$ has good optical and electrical characteristics such as refractive index, high dielectric permittivity and electrical conductivity. ${ }^{3}$ Furthermore, bismuth oxide has wide energy band gap (2 $3.96 \mathrm{eV}) .{ }^{4}$ Therefore, due to its potential properties, bismuth oxide is used in various applications for examples: solid oxide fuel cell, ${ }^{5}$ electrode,${ }^{6}$ gas sensor, ${ }^{7}$ and degradation of dye molecules through photocatalysis. ${ }^{8-13}$

This metal oxide can be prepared by several methods, such as precipitation, ${ }^{8,9,14,15}$ solution combustion, ${ }^{10,16}$ hydrothermal, ${ }^{17}$ and sol gel methods. ${ }^{18}$ In this study, bismuth oxide was prepared by solution combustion method because it has several advantages such over other methods that are fast and easy processing, shorter reaction times, high purity and homogenity of the product, and nanosized powder product. ${ }^{19}$ Solution combustion method is a synthesis method whose main components consist of oxidant and fuel, and the process involves high temperature. ${ }^{19}$

Factors that can influence the synthesis using the solution combustion method include the ratio of fueloxidant, temperature, flame type and the amount of gas produced. In this study, bismuth oxide was prepared by solution combustion method with variation of fuel-oxidant ratio $(\phi)$. The fuel-oxidant $(\phi)$ ratio can affect the morphology, crystal structure, and particle size of the resulting products. The fuel-

Rasayan J. Chem., 12(4), 2210-2217(2019)

http://dx.doi.org/10.31788/RJC.2019.1245323

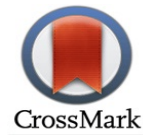


RASĀYAN J. Chem.

Vol. 12 | No. 4 |2210 - 2217| October - December | 2019

oxidant $(\phi)$ ratio determines the gas amount formed. Gas formed during the reaction disintegrades the cluster and forms pores in the material. The greater the amount of the fuel, the more gas formed; consequently, the greater pores formed as well. Moreover, the resulting particle size is also smaller since the gas formed inhibits the growth of the particles. ${ }^{19}$

La et al. ${ }^{16}$ synthesized bismuth oxide using solution combustion method with variation of fuel-oxidant ratio $1.2,0.8$ and 0.6 . The fuel used was citric acid, while the oxidant used was bismuth nitrate pentahydrate. The resulting product was $\beta-\mathrm{Bi}_{2} \mathrm{O}_{3}$ (tetragonal) at the ratio of fuel-oxidant 1.2 and 0.8 , while the ratio of fuel-oxidant 0.6 resulted in a mixture of $\alpha-\mathrm{Bi}_{2} \mathrm{O}_{3}$ (monoclinic) and $\beta-\mathrm{Bi}_{2} \mathrm{O}_{3}$ (tetragonal). In term of particle size, product synthesized using a ratio of fuel-oxidant 1.2 had a material size of $20-30 \mathrm{~nm}$, while for the fuel-oxidant ratio of 0.8 generated large agglomerated product. Eventhough La et $\mathrm{al}^{16}$ synthesized bismuth oxide using solution method with variation of fuel-oxidant ratios, the impact of difference ratio of fuel-oxidant on the photocatalytic activity has not been explored yet. Therefore, in this study, bismuth oxide fabrication was carried out by solution combustion method with a variety of fueloxidant $(\phi)$ ratios, namely $\phi>1, \phi=1$, and $\phi<1$ in order to determine the impact of the ratio of fueloxidant on the physicochemical properties and photocatalytic performance of the obtained products. The oxidant and fuel used were bismuth nitrate pentahydrate and citric acid, respectively.

\section{Materials}

\section{EXPERIMENTAL}

Materials used were bismuth nitrate pentahydrate $\left(\mathrm{Bi}\left(\mathrm{NO}_{3}\right)_{3} .5 \mathrm{H}_{2} \mathrm{O}\right)$ from Sigma-aldrich, $\mathrm{HNO}_{3}(65 \%$, v/v), $\mathrm{NH}_{4} \mathrm{OH}(25 \%, \mathrm{v} / \mathrm{v})$, polyethylene glycol (PEG 20000), methyl orange, citric acid monohydrate $\left(\mathrm{C}_{6} \mathrm{H}_{8} \mathrm{O}_{7} \cdot \mathrm{H}_{2} \mathrm{O}\right)$ and distilled water purchased from Merck Index, Indonesia without further purification and in analytical grades.

\section{General procedure}

Synthesis of bismuth oxide by solution combustion method follows the method recommended by La et al. ${ }^{16}$ with slight modification. Fuel-oxidant $(\phi)$ ratios used in this study were $\phi>1$ with a value of $1.2 ; \phi=$ 1 , and $\phi<1$ with a value of 0.8 .

Synthesis of bismuth oxide with fuel-oxidant ratio $\phi>1$ started with adding of 2.9106 gram $\mathrm{Bi}\left(\mathrm{NO}_{3}\right)_{3} .5 \mathrm{H}_{2} \mathrm{O}$ in $10 \mathrm{~mL}$ of $\mathrm{HNO}_{3} 0.04 \mathrm{M}$. The mixture was stirred until homogeneous with speed of $1000 \mathrm{rpm}$. Next, 0.04 gram of PEG and 1.471 gram of citric acid was added into the mixture and stirred in $1200 \mathrm{rpm}$ for 5 minutes until the solution was in transparent form. The clear transparent solution formed was then heated at $300{ }^{\circ} \mathrm{C}$ for 8 hours. The formed product was calcined at $700{ }^{\circ} \mathrm{C}$ for 4 hours. As a result, a yellow powder was formed and used for further characterization and photocatalytic activity test. This procedure was also performed on the synthesis of bismuth oxide with variations in the fuel-oxidant ratio $\phi=1$ and $\phi<1$ by changing the amount of $\mathrm{Bi}\left(\mathrm{NO}_{3}\right)_{3} .5 \mathrm{H}_{2} \mathrm{O}$ which was added.

\section{Characterisation Method}

The characterization techniques used for products analysis were XRD, FTIR, TGA and SEM. The XRD instrument used $\mathrm{CuK} \alpha$ as the radiation source, $30 \mathrm{kV}$ voltage, $30 \mathrm{~mA}$ electricity, the lengh of radiation wave X-ray $1.54178 \AA$ and $2 \theta$ ranging from $10^{\circ}$ to $90^{\circ}$. Diffractograms from XRD analysis were compared with joint comitte on powder diffraction standard (JCPDS) database to identify the crystal structure of products. FTIR Prestige 21 (Shimadzu) with wavenumber scanning of $400-4000 \mathrm{~cm}^{-1}$ was applied to obtain FTIR spectra.A thermogravimetric curves were recorded from TGA 4000 Perkin Elmer at the temperature range of $50-700{ }^{\circ} \mathrm{C}$ with heating rate of $5{ }^{\circ} \mathrm{C} / \mathrm{min}$ under nitrogen stream. SEM images were obtained using JEOL-JSM-6510LV microscope.

\section{Photocatalytic Activity Test}

Photocatalytic performance test of the obtained products was conducted in a reactor photocatalyst, using methyl orange $5 \mathrm{ppm}$. It was undertaken without and with light irradiation. For the photocatalytic activity test without light irradiation, $50 \mathrm{~mL}$ of methyl orange was added 0.1 gram of the obtained product. Subsequently, the mixture was stirred in medium speed $(667 \mathrm{rpm})$ for 2 hours. While for photocatalytic 
RASĀYAN J. Chem.

Vol. 12 | No. 4 |2210 - 2217| October - December | 2019

activity test under ultraviolet (UV) light the procedure was the same however the samples were under UV irradiation in different times that were 2, 4, 6, 8, and 10 hours. After that, the mixture was filtered and filtrate was analyzed using UV-Vis spectrophotometer to determine the absorbance which further to calculate degradation percentage of methyl orange by bismuth oxide.

\section{Synthesis of Bismuth Oxide Using Combustion Method \\ RESULTS AND DISCUSSION}

Bismuth oxide synthesis started with dissolving bismuth nitrate pentahydrate $\left(\mathrm{Bi}\left(\mathrm{NO}_{3}\right)_{3} \cdot 5 \mathrm{H}_{2} \mathrm{O}\right)$ in nitric acid solvent and formed homogeneous suspension with cloudy white in colour. The suspension was then added polyethylene glycol (PEG) and citric acid then stirred at high speed (1200 rpm) to form transparent solution. According to Li et al, ${ }^{20}$ the role of PEG is to prevent agglomeration; PEG is to slow the rate of diffusion of solutes from the nucleus formed to the surface of the crystal, while the diffusion process is a rate determinant during crystal growth. By the slow crystal growth, the product generated would have a more homogeneous morphology and smaller particle size.

The transparent solution formed had been heated at $300{ }^{\circ} \mathrm{C}$ for 8 hours. This process produced gases of $\mathrm{CO}_{2}, \mathrm{~N}_{2}$, and $\mathrm{H}_{2} \mathrm{O} .{ }^{21}$ The transparent solution heated for 8 hours resulted in powder with brownish yellow mixed with black in colour as seen in Fig.-1. The black colour in the samples indicated the presence of carbon derived from citric acid. During the heating process there was also the formation of purplish pink smoldering flame. Smoldering type flame cannot be long-lasting, sometimes it doesn't even appear. This flame is formed from the release of heat from the combustion process. ${ }^{19}$

Powder with yellow in colour was formed when calcination at $700{ }^{\circ} \mathrm{C}$ for 4 hours was applied as presented in Fig.-2. This yellow colour powder indicated physical appearance that bismuth oxide was formed. Percentage yields of bismuth oxide with a ratio of $\phi>1, \phi=1$, and $\phi<1$ were $66.43 \%, 74.26 \%$ and $65.71 \%$, consecutively. According to Mukasyan et al, ${ }^{21}$ the mechanism occured during the calcination process is :

$$
2 \mathrm{Bi}\left(\mathrm{NO}_{3}\right)_{3} \cdot 5 \mathrm{H}_{2} \mathrm{O}+\mathrm{C}_{6} \mathrm{H}_{8} \mathrm{O}_{7} \cdot \mathrm{H}_{2} \mathrm{O}+\mathrm{O}_{2} \stackrel{\text { calcination }}{\longrightarrow} \quad \mathrm{Bi}_{2} \mathrm{O}_{3}+6 \mathrm{CO}_{2}+9 \mathrm{H}_{2} \mathrm{O}+3 \mathrm{~N}_{2}
$$
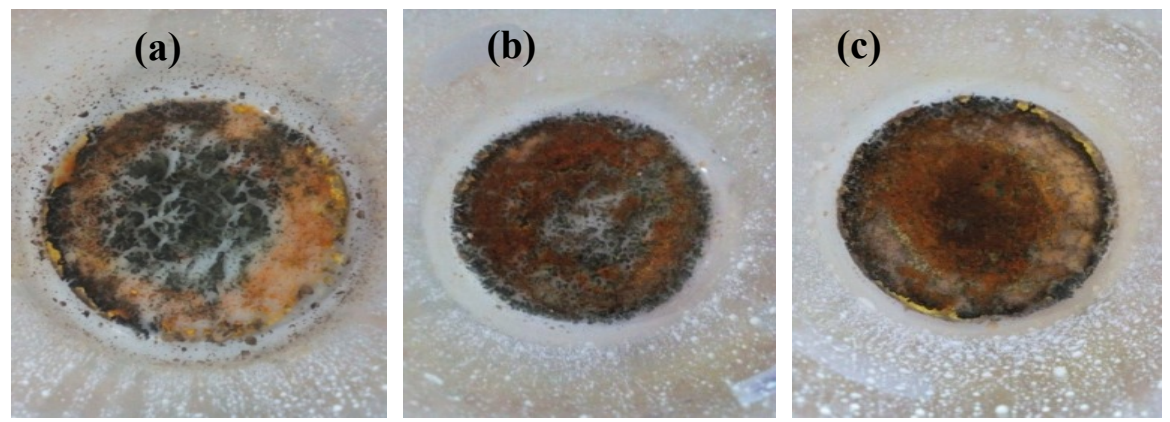

Fig.-1: The Physical Appearance Of The Transparant Solution of(a) $\phi>1$, (b) $\phi=1$, (c) $\phi<1$ After Heating For 8 Hours
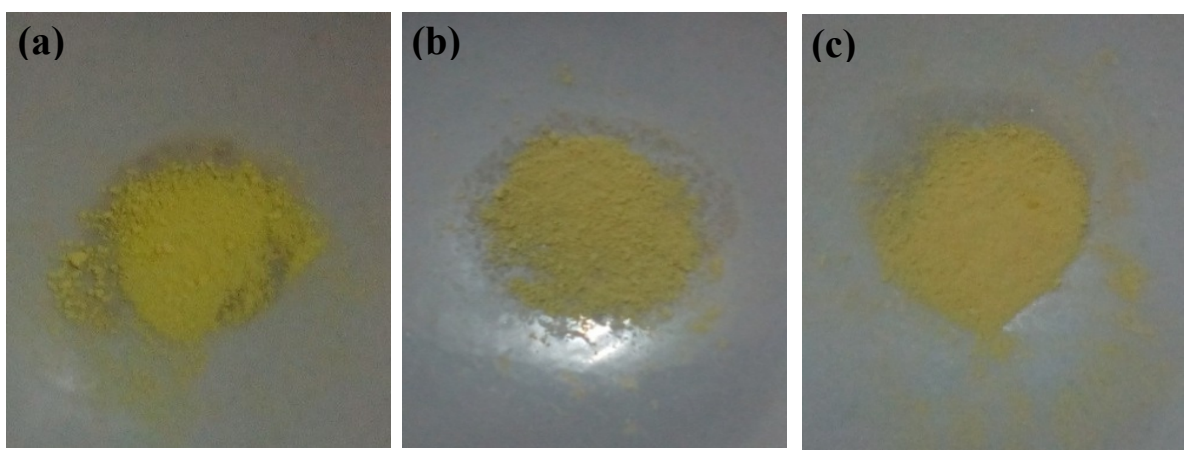

Fig.-2: The Physical Appearance Of The Products With ratio of (a) $\phi>1$; (b) $\phi=1$; (c) $\phi<1$ after Calcination 
RASĀYAN J. Chem.

Vol. 12 | No. 4 |2210 - 2217| October - December | 2019

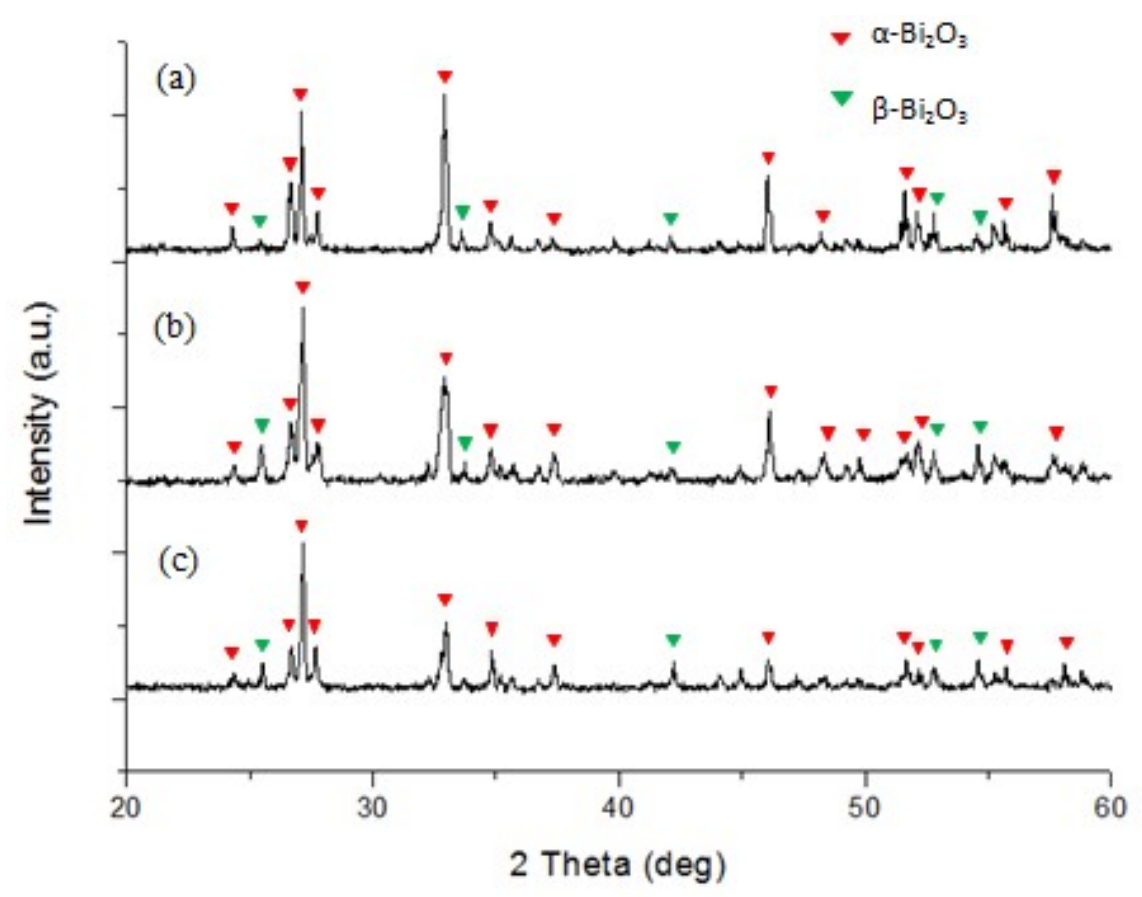

Fig.-3: Diffractograms of Products Synthesized With Fuel-Oxidant Ratio of (a) $\phi>1$, (b) $\phi=1$, (c) $\phi<1$

In order to identify that the bismuth oxide synthesis was successful, the products were then analyzed using XRD to determine the product's crystal structures. Figure-3 presents the diffractograms of products synthesized with a variety of fuel-oxidant ratios.

The presence of $\alpha-\mathrm{Bi}_{2} \mathrm{O}_{3}$ is indicated by a peak at $2 \theta$ of $27.10,32.92$, and 46.05 for product with ratio of $\phi>1$; at $2 \theta$ of $27.13,32.90$, and 46.10 for product with ratio of $\phi=1$, and at $2 \theta$ of $27.16,32.93$, and 46.07 for product with ratio of $\phi<1$. Those data are consistent with the JCPDS database number 41-1449 for $\alpha-$ $\mathrm{Bi}_{2} \mathrm{O}_{3}$. The presence of $\beta-\mathrm{Bi}_{2} \mathrm{O}_{3}$ is marked with a peak condition at $2 \theta$ of $25.49,42.11$, and 54.51 for product with a ratio of $\phi>1$; at $2 \theta$ of $25.50,42.15$, and 54.57 for product with ratio of $\phi=1$, and at $2 \theta$ of $25.56,42.21$, and 54.59 for product with ratio of $\varphi<1$. This is consistent with the JCPDS database with number 27-0050 for $\beta-\mathrm{Bi}_{2} \mathrm{O}_{3}$. The crystal structures of the products synthesized using solution combustion method with a variation ratio of $\phi>1, \varphi=1$ and $\varphi<1$ are a mixture of $\alpha-\mathrm{Bi}_{2} \mathrm{O}_{3}$ (monoclinic) and $\beta-\mathrm{Bi}_{2} \mathrm{O}_{3}$ (tetragonal). This result is in agreement with $\mathrm{La}$ et $\mathrm{al}^{16}$ report. This suggests that the variation of the ratio of fuel-oxidant $(\phi)$ has no effect on the crystal structure of the obtained products.

The FTIR spectroscopy technique was also applied to identify the functional groups indicating the presence of bismuth oxide. Figure-4 shows the FT-IR spectra of all the products synthesized in different fuel-oxidant ratio. The intense band at $2250-2100 \mathrm{~cm}^{-1}$ region is attributed to the vibration mode of the alkyne. ${ }^{22}$ The presence of vibration mode C-C attributed to alkyne is probably because of incomplete reaction of citric acid as fuel yet the intensity of this vibration mode is low. Furthermore, the peak at 844 $\mathrm{cm}^{-1}$ is due to $\mathrm{Bi}-\mathrm{O}$ stretching vibration. ${ }^{23}$ The intense band at $1200-1700 \mathrm{~cm}^{-1}$ possibly arises due to stretching vibrations of the $\mathrm{NO}_{3}$ ion, which may come from bismuth nitrate $\mathrm{Bi}\left(\mathrm{NO}_{3}\right)_{3} .{ }^{24}$ All the products show no significant difference in FTIR spectra.

Changes of the samples before calcination as seen in Fig.-1 that occurred during the calcination process can be identified using TGA analysis by calculating mass changes as a result of the gradual increase in temperature. One of the samples before and after calcination as shown in Fig.-1 and Fig.-2 respectively was analyzed using TGA. Figure-5 shows the TGA curves of the sample before (Fig.-5a) and after calcination (Fig.-5b). TGA curve of the sample before calcination shows that there are three regions of mass weight loss on the TG curve. The first area at the temperature of $34.0-50.8^{\circ} \mathrm{C}$ is associated with 
RASĀYAN J. Chem.

Vol. 12 | No. 4 |2210 - 2217| October - December | 2019

the decomposition of bismuth nitrate pentahydrate $\left(\mathrm{Bi}\left(\mathrm{NO}_{3}\right)_{3} \cdot 5 \mathrm{H}_{2} \mathrm{O}\right) .{ }^{25}$ The second area occurred at the temperature of $265-319.8^{\circ} \mathrm{C}$ which may be due to reduced or lost organic matter such as citric acid. The total loss of organic matter is in the region of $\sim 398{ }^{\circ} \mathrm{C}$. The relative mass changes of the sample before calcination were $1.64292(\%), 3.36388(\%)$, and $2.14636(\%)$. While the TGA curve of sample after calcination shows no relative mass change significantly which is probably the formation of bismuth oxide was almost complete. Compared to TGA curve of sample before calcination, the relative mass change of sample after calcination is smaller than that before calcination.

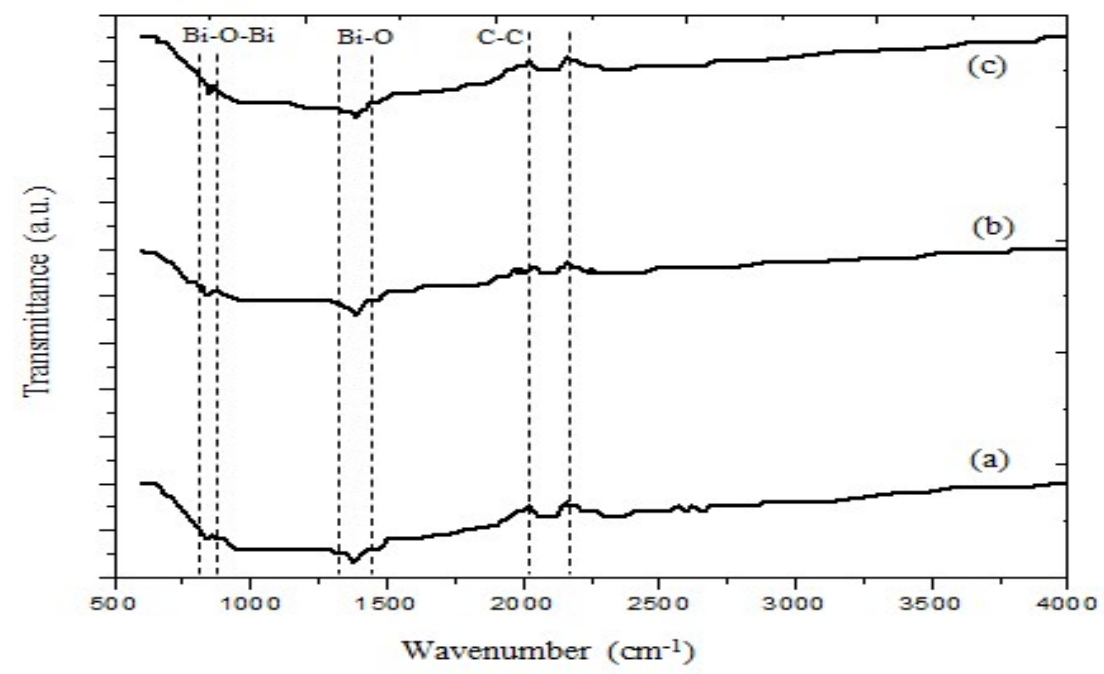

Fig.-4: FT-IR Spectra Of Products Synthesized By Citric Acid-Bismuth Oxide Ratio of (a) $\phi=1$; (b) $\phi<1$; (c) $\phi>1$

The morphology and particle size of the products were then analyzed using SEM. Figure- 6 shows the SEM images of the products. It can be seen that all samples have similar morphology, that is irregular shapes, coral reefs-like and in agglomerate forms, with the size of 5-8 $\mu \mathrm{m}, 6-10 \mu \mathrm{m}$, and 9-14 $\mu \mathrm{m}$ for products synthesized with $\phi>1, \phi=1$, and $\phi<1$ consecutively. The bigger the fuel-oxidant ratio $(\phi)$, the smaller the particle size. The fuel-oxidant $(\phi)$ ratio determines the amount of gas formed. The gas formed during the reaction disintegrates the cluster and form pore in the material. The greater the amount of the fuel, the more gas formed; consequently, the resulting particle size is smaller since the gas formed inhibits the growth of the particles. ${ }^{19}$

\section{Photocatalytic Activity}

The products were applied for methyl orange degradation under ultraviolet light by time interval of $2-10$ hours. The absorbance of methyl orange solution after photocatalysis was measured using UV-Vis spectrophotometry with a maximum wavelength of $465 \mathrm{~nm}$.

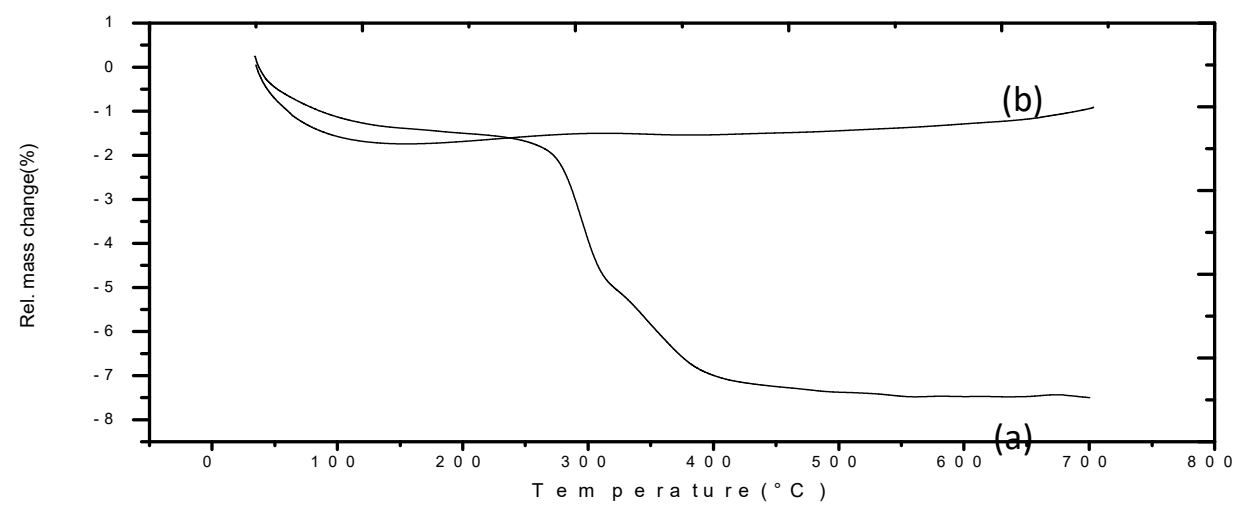

Fig.-5: Thermogram Bismuth Oxide (A) Before Calcination; (B) After Calcination 
RASĀYAN J. Chem.

Vol. 12 | No. 4 |2210 - 2217| October - December | 2019
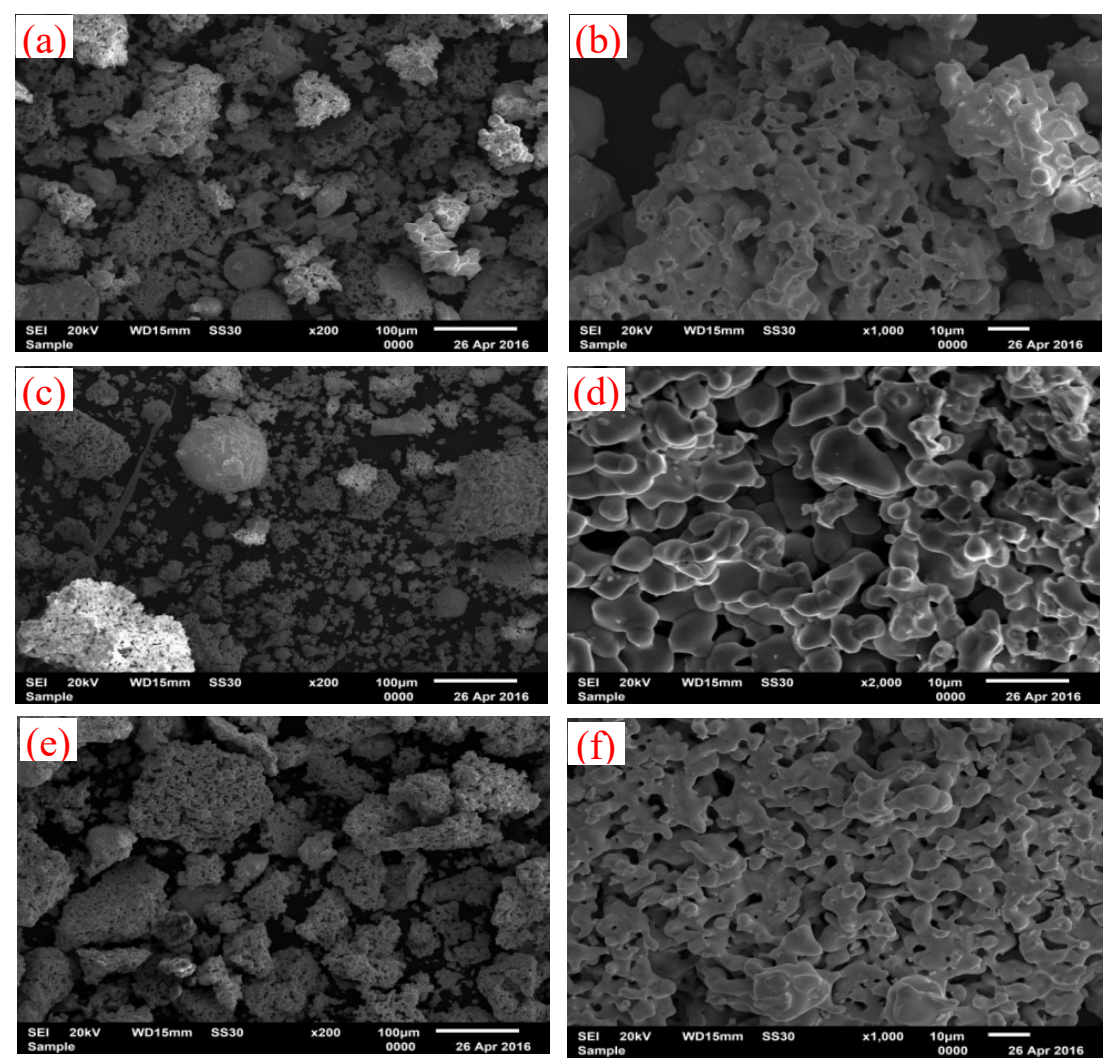

Fig.-6: SEM Images of Products Synthesized With Citiric Acid-Bismuth Netrate Pentahydrate of (A) $\Phi>1$, (C) $\Phi=1$,

(E) $\Phi<1$ With The Magnification of 200x; And of (B) $\Phi>1$, (F) $\Phi<1$ (D) $\Phi=1$ With Magnification of 1000x.

Figure-7 shows the percentage of degradation of methyl orange after photocatalysis using the three samples. It shows that during the 10 hours of the photocatalysis, products synthesized with a ratio of $\phi>1$, $\phi=1$, and $\phi<1$ degraded methyl orange for $38.53 \%, 13.34 \%$ and $38.02 \%$ consecutively. Products with a ratio of $\phi>1$ ) have the best photocatalytic activity for methyl orange degradation because the high fueloxidant ratio $(\phi)$ generated the smaller particle size of product. ${ }^{19}$ The smaller particle size the greater the surface area; consequently contact between methyl orange and particles is also high. As a result, photocatalytic activity increases. This is in agreement with SEM image as presented in Fig.-6a and $6 \mathrm{~b}$ that product synthesized with fuel-oxidant ratio of $\phi>1$ has the smaller particles compared to other products.

The mechanism of methyl orange degradation has been proposed by Liu et al. ${ }^{26}$ When the bismuth oxide is illuminated by light, the electrons will be excited from the valence band to the conduction band, and the hole electrons will be formed in the valence band. Then $\mathrm{OH}^{-}$ions that come from water adsorbed on the surface of bismuth oxide react with holes of electrons and form $\cdot \mathrm{OH}$ radicals and $\mathrm{H}^{+}$ions. ${ }^{26} \mathrm{On}$ the semiconductor surface, electrons in the conduction band react with atmospheric $\mathrm{O}_{2}$ to form ${ }^{-} \mathrm{O}_{2}{ }^{-}$. In addition, $\cdot \mathrm{O}_{2}{ }^{-}$can be another source of $\bullet \mathrm{OH}$ formation after protonation process. Radical of hydroxyl $(\cdot \mathrm{OH})$ is a potential substance for oxidation of methyl orange into simpler molecules that are $\mathrm{CO}_{2}$ and $\mathrm{H}_{2} \mathrm{O}$ when the reaction is complete. ${ }^{26}$

Wang et al. ${ }^{[27]}$ reported that the activity of dye molecules degradation generally follows the first-order kinetics, which is formulated by the equation:

$$
\ln C_{t}=\ln C_{0}-k t
$$

with $\mathrm{k}$ is degradation rate constant in the first-order kinetics model $\left(\mathrm{s}^{-1}\right) ; \mathrm{C}_{0}$ and $\mathrm{C}_{\mathrm{t}}$ is methyl orange concentration at $\mathrm{t}=0$ and $\mathrm{t}$ time $(\mathrm{ppm})$, respectively.

Figure 8 shows the first orde kinetics model of the degradation of methyl orange. The degradation rate constant of methyl orange by-products synthesized with citric acid-bismuth nitrate pentahydrate ratio of 
RASĀYAN J. Chem.

Vol. 12 | No. 4 |2210 - 2217| October - December | 2019

$\phi>1, \phi=1$ and $\phi<1$ are $97.20 \mathrm{~s}^{-1}, 47.52 \mathrm{~s}^{-1}$, and $95.76 \mathrm{~s}^{-1}$, respectively. Product with a ratio of $\phi>1$ has the highest reaction rate constant degradation of methyl orange, it is in accordance with the highest photocatalytic performance of the methyl orange degradation as seen in Fig.-7.

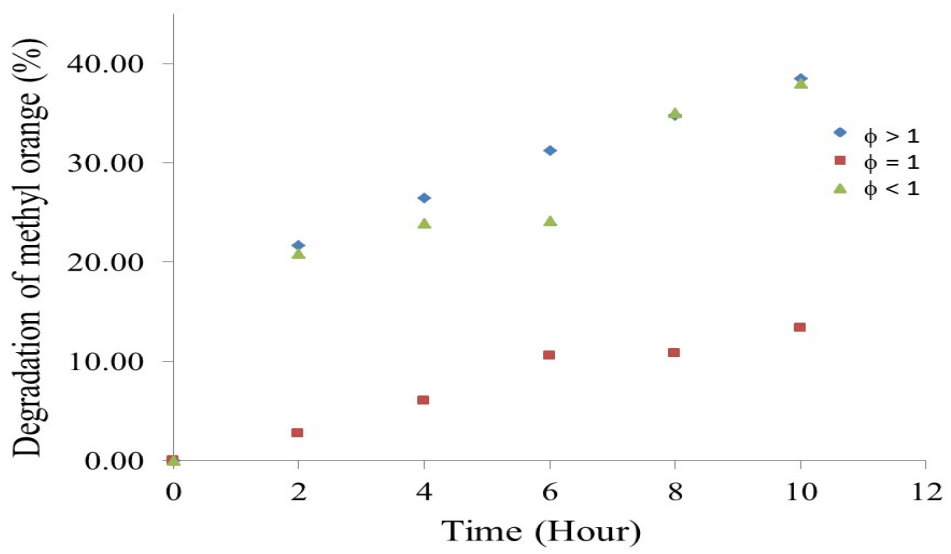

Fig.-7: The Degradation Percentage of Methyl Orange By All The Products

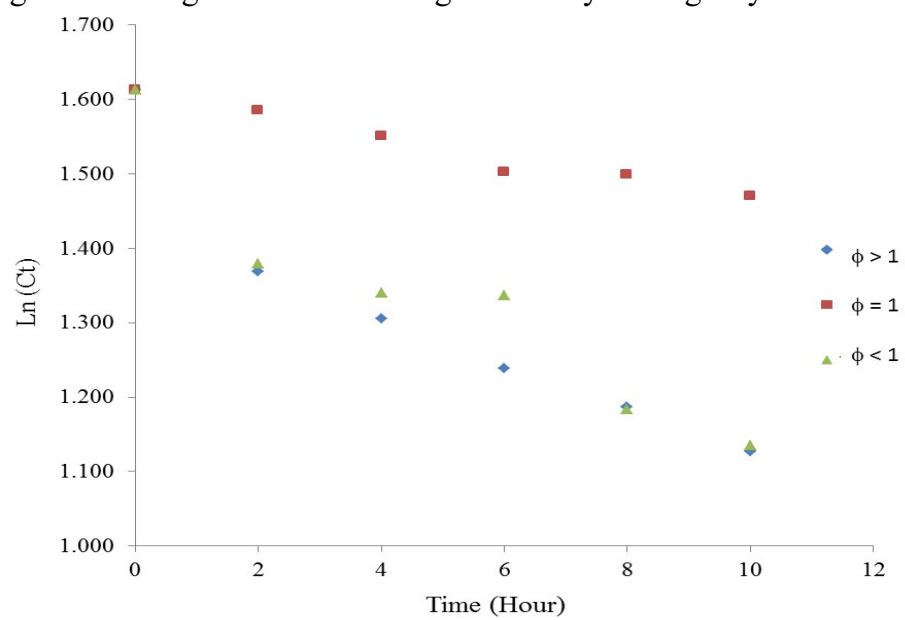

Fig.- 8: First Orde Reaction Kinetic on The Methyl Orangedegradation

\section{CONCLUSION}

The citric acid-bismuth nitrate pentahydrate ratio affected the photocatalytic activity of the bismuth oxide prepared by solution combustion method. The photocatalytic performance of obtained products with a ratio of $\phi>1$ showed the highest activity on the degradation of methyl orange under light irradiation. Meanwhile, the crystal structures of the products synthesized with a variation ratio of $\phi>1, \phi=1$ and $\phi<1$ are a mixture of $\alpha-\mathrm{Bi}_{2} \mathrm{O}_{3}$ (monoclinic) and $\beta-\mathrm{Bi}_{2} \mathrm{O}_{3}$ (tetragonal) suggesting that the variation of citric acid-bismuth nitrate pentahydrate (fuel-oxidant) ratio $(\phi)$ has no effect on the crystal structure of the products. However, this fuel-oxidant ratio does influence the particle size of the products.

\section{ACKNOWLEDGMENT}

Thank the Ministry of Research, Technology and Higher Education, Republic of Indonesia for financial support through "Hibah Kompetensi" scheme with grant no. 125/SP2H/PTNBH/DRPM/2018 and 10171/UN7.P4.3/PP/2019.

\section{REFERENCES}

1. M. Mallahi, A. Shokuhfar, M.R.Vaezi, A. Esmaeilirad, V. Mazinani, AJER, 3, 162 (2014)

2. S. Yilmaz, O. Turkoglu, M. Ari, I. Belenli, Cerâmica, 57, 185 (2011), DOI:10.1590/S036669132011000200009 
RASĀYAN J. Chem.

Vol. 12 | No. 4 |2210 - 2217| October - December | 2019

3. C.M.B Hincapie, M.J.P Cárdenas, J.E.A.Orjuela, E. R. Parra, Dyna., 79, 139 (2012)

4. Y.Qiu, M.Yang, H.Fan, Y.Zuo, Y.Shao, Y. Xu, X.Yang, S.Yang, Mater. Lett., 65, 780 (2011), DOI: 10.1016/j.matlet.2010.11.045

5. Y. E. Gönen, I. Ermiş, M. Ari, Phase Transit., 89, 1129 (2016), DOI:10.1080/01411594.2016.1150471

6. E. Demir, S. Hayat-Soytas, R. Demir-Cakan, Solid State Ionics, 342, 115066 (2019), DOI:10.1016/j.ssi.2019.115066

7. E.Y.Febrianto, N.Indayaningsih, J. Fis. Himp. Fis. Ind., 9, 12(2009)

8. Y. Astuti, R. Andianingrum, A. D. Wulansari, A. Haris, Adv. Sci. Lett., 23, 6521(2017), DOI: 10.1166/asl.2017.9671

9. Y. Astuti, Arnelli, Pardoyo, A. Fauziyah, S. Nurhayati, A. D. Wulansari, R. Andianingrum, H. Widiyandari, G. A. Bhaduri, Bull. Chem. React. Eng., 12, 478(2017), DOI: 10.9767/bcrec.12.3.1144.478-484

10. Y. Astuti, A. Fauziyah, S. Nurhayati, A. D. Wulansari, R. Andianingrum, A. R. Hakim, G. Bhaduri, IOP Conf. Ser. Mater. Sci. Eng., 107, 012006 (2016), DOI:10.1088/1757-899X/107/1/012006

11. S. Iyyapushpam, S. T. Nishanthi, D. P. Padiyan, Mater. Lett., 86, 25(2012), DOI: 0.1016/j.matlet.2012.07.015

12. X. Liu, L. Pan, T. Lv, Z. Sun, C. Q. Sun, J. Colloid Interf. Sci., 408, 145(2013), DOI:10.1016/j.jcis.2013.07.045

13. G.-D.Lim, J-H. Yoo, M. Ji, Y-I. Lee, J. Alloy. Compd., 806,1060(2019), DOI:10.1016/j.jallcom.2019.07.319

14. R. Hernandez-Delgadillo, D. Velasco-Arias, J. J.Martinez-Sanmiguel, D. Diaz, I. Zumeta-Dube, K. Arevalo-Niño, C. Cabral-Romero, Int. J. Nanomed., 8, 1645 (2013), DOI: 10.2147/IJN.S38708

15. Y. Astuti, H. Ningsih, Arnelli, A. Darmawan, AIP Conf. Proc., 2026, 020002(2018), DOI: $10.1063 / 1.5064962$

16. J. La, Y. Huang, G. Luo, J. Lai, C. Liu, G. Chu, Particul. Sci. Technol., 31, 287(2013), DOI: $10.1080 / 02726351.2012 .727525$

17. C. Wu, L. Shen, Q. Huang, Y-C. Zhang, Mater. Lett., 65, 1134(2011), DOI: 10.1016/j.matlet.2011.01.021

18. M. Anilkumar, R. Pasricha, V. Ravi, Ceram. Int., 31, 889(2005), DOI: 10.1016/j.ceramint.2004.09.002

19. A. K. Alves, C. P. Bergmann, F. A. Berutti, Novel synthesis and characterization of nanostructured materials, Springer, New York, (2013)

20. W. Li, Mater. Chem. Phys., 99, 174 (2006), DOI: 10.1016/j.matchemphys.2005.11.007

21. A. S. Mukasyan, P. Epstein, P. Dinka, Proc. Combust. Inst., 31, 1789 (2007), DOI: 10.1016/j.proci.2006.07.052

22. N. Colthup, Introduction to Infrared and Raman Spectroscopy, Elsevier, New York, (2012)

23. V. Fruth, M., Popa, D. Berger, C. M. Ionica, M. Jitianu, J. Eur. Ceram. Soc., 24, 1295 (2004), DOI: 10.1016/S0955-2219(03)00506-5

24. H. Fu, C. Pan, W. Yao, Y. Zhu, J. Phys. Chem. B, 109, 22432 (2005), DOI: 10.1021/jp052995j

25. C. Mukhopadhyay, A. Datta, Catal. Commun., 9, 2588 (2008), DOI: 10.1016/j.catcom.2008.07.019

26. X. Liu, H. Deng, W. Yao, Q. Jiang, J. Shen, J. Alloy. Compd., 651, 135 (2015), DOI: 10.1016/j.jallcom.2015.08.068

27. Q. Wang, J. Hui, L. Yang, H. Huang, Y. Cai, S. Yin, Y. Ding, Appl. Surf. Sci., 289, 224 (2014), DOI: $10.1016 /$ j.apsusc.2013.10.139

[RJC-5323/2019] 